\title{
Actor Roles in the Service Development Process
}

\author{
Patrik Gottfridsson, Karlstad University
}

\begin{abstract}
The purpose of this study is to increase understanding of the different actors participating in the service development process, the roles they play, and the resources they contribute to the process. The public transport system in Sweden is a complex setting in which many actors control a variety of resources. Using the established tripartite network model (actors, activities, and resources), the present study identifies eight groups of actors: (1) the Strategic Creators; (2) the Competing Actors; (3) the Deciding Actors; (4) the Supporting Actors; (5) the Prime Movers; (6) the Suppliers; (7) the Service Performers, and (8) the Users. The primary contribution of this paper is to identify this novel typology of actors in the service development process. The study also proposes a conceptual model of the relationships among these various actors and their functions.
\end{abstract}

\section{Introduction}

In virtually all service industries, interactions and collaborations among various actors are vital ingredients of both the service offering (Grönroos 1990) and the service system; in particular, the service system consists of a network of interrelated actors and resources required to deliver the service (Edvardsson 1997). In many cases, these actors and resources are external to the focal organization, which is dependent on resources held by others and must interact with these external actors to obtain the necessary resources (de Burca 1995; IMP 1982).

The important role that is played by external actors and resources in the service offering and the service system implies that interaction and coordination among 
different actors and their resources should also form an important aspect of the service-development process. If new or refined service offerings are to be developed efficiently, there is an obvious need for service developers to know which actors participate in the service offering and the service system and what resources they bring to the process. However, despite the apparent importance of interaction and collaboration in service development, a review of the literature reveals that interactions and collaborations among various actors have been largely overlooked in research into the service development process (see, for example, Akamavi 2005; Smith and Fischbacher 2005, Jong and Vermeulen 2003; Johne and Storey 1998); indeed, according to Smith and Fischbacher (2005), no studies have assessed the impact that various actors have on the service development process. As a result, existing service development models do not provide an accurate picture of how new services are actually developed (Stevens and Dimitriadis 2004; Akamavi 2005).

In addressing this apparent deficiency in the literature, the aims of the present study are to identify the actors involved in the service-development process, analyse the roles that these actors play, and identify the resources they bring to the process. To the extent that it realizes these objectives, the main contribution of this paper is to present a typology of the various actors involved in the service development process and a proposed model of the relationships among the various actors and their functions.

The remainder of this paper is organized as follows. The following section presents a conceptual framework for the study, including a literature review of relevant studies in this area. The paper then presents the methodology of the empirical study and a summary of the six case studies from which empirical data are collected. This is followed by a presentation of the results, including the identification of eight categories of actors and their functions. The paper then discusses the significance of the findings and suggests a proposed model of the relationships among the different actors and their functions. The paper concludes with a summary of the main conclusions, managerial implications, and suggestions for future research.

\section{Conceptual Framework}

\section{Models of the Service Development Process}

If we look at service development research, the existing service-development models can be, according to Johnson et al. (2000), divided into three broad categories. 
The first category is constituted by the "partial models," which describe certain aspects of the service development process. The second category includes the socalled "translational models," which largely draw on models of the development of physical goods and then translate this knowledge into the service area. The third category includes the "comprehensive models," which attempt to describe service development in terms of its own parameters and merits. Most of the service development models adopt a sequenced approach. For example, Scheuing and Johnston's (1989) model consisted of 15 steps for how services are (or at least ought to be) developed. Other models have contained fewer steps and less linear approaches to service development (Akamavi 2005; Johne and Storey 1998; Jong and Vermeulen 2003). Despite these differences, Lievens et al. (1999) identified three broad phases in the service development process: the planning phase, the development phase, and the market launch phase. Although most of the models imply that the development of services is carried out in a structured way, service development processes are, in reality, seldom as structured as the models suggest (Bowers 1988; Edgett 1996; Johne and Storey 1998; Martin and Horne 1993). In particular, there is considerable overlap between the designated phases.

Besides this, most service development models adopt, according to Johne and Storey (1998), who undertook a thorough review of the literature on new service development, an intra-organizational perspective-that is, they focus on what is happening within the organisation and how the different phases of the development process have been carried out (or should have been carried out). Subsequent literature reviews (Akamavi 2005; Jong and Vermeulen 2003) have painted an essentially similar picture. In contrast to this, other researchers argue that a company's activities are not performed in isolation; rather, they are embedded to varying degrees in a wider web of coordinated business activities with other companies and agents (Ford 1997; de Burca 1995). Most companies are dependent on resources held by other parties. To obtain access to these resources, companies need to interact within networks of relationships (Ford 1997; de Burca 1995). A network is composed of three interrelated variables-actors, activities, and resources (Håkansson and Johansson 1992). Of these, the actors play the crucial networking role because they perform the activities and control the resources. These actors can be individuals or groups; indeed, they can be an organization or a part of an organisation. The resources can be divided into tangible resources and intangible resources. Examples of tangible resources include physical assets (such as production equipment, components, and materials). Examples of intangible resources include knowledge, skills, and routines. Resources can be under 
the control of a single actor or jointly controlled by several actors. Based on the resources, the actors undertake activities where the resources are either transformed by being combined with other resources or transferred between actors. If the resources are in short supply, or if they are important for either transformation or transfer, the question of who controls them assumes greater significance (Håkansson and Johansson 1992; IMP 1982).

This preoccupation with an intra-organizational focus has resulted in that the interactive and collaborative aspects of service development have largely been overlooked (Syson and Perks 2004). As a result, the existing service development models overlook important aspects of the service logic and therefore do not provide an accurate picture of how services are actually developed (Akamavi 2005; Stevens and Dimitriadis 2004).

\section{Actors in the Service-Development Process}

Despite the relative paucity of studies on the interactive and collaborative aspects of the service development process, there have been some studies that have examined the various actors (or actor groups) in the process. For example, Syson and Perks (2004) studied service development from a network perspective with a focus on the interactions among actors. Utilizing a case study of the development of services at a building society, the authors identified the network actors who were involved in the development process. These included internal actors (members of the designated product development team, other internal actors who contributed financial, marketing, and legal expertise, and customer-contact staff) and external actors (such as competitors, distributors, agents, customers, and suppliers).

Another study of the development process from a network perspective was conducted by Heikkinen et al. (2007), who drew on so-called "role theory" to identify 12 distinct management roles in the development of a business network. Using such criteria as whether a task was "radical" (or "incremental") and whether it was "expected" (or "emerging"), the authors identified the following roles: Webber, Instigator, Producer, Facilitator, Gatekeeper, Entrant, Aspirant, Planner, Compromiser, Advocate Auxiliary, and Accessory Provider.

Actors or actor groups in the service development process also have been mentioned in some other studies. For example, Edvardsson (1997), who focused on quality in new service development, noted that service is produced by a process that includes the customer, the company, and subcontractors as actors. Other authors who have identified customers or users as important players in the service 
development process include Berry and Hensel (1973), Pitta and Franzak (1996), and von Hippel et al. (1999); similarly, frontline staff have also been accorded an important role in the process by such authors as Schneider and Bowen (1985), Atuahene-Gima (1996), and Edvardsson et al. (2000). The role of the supplier in the study by Syson and Perks (2004) is in accordance with the recognition that most companies are dependent on resources held by others (Ford 1997; de Burca 1995).

\section{Research Methodology}

\section{Background to the Study and Summary of Cases}

Responsibility for public transport in Sweden is distributed among several actors (SLTF 2002) who must actively collaborate within various networks to create and provide the public transport system. The level of complexity is, therefore, high because many actors are involved on various levels, all of whom have different degrees of authority, varying access to resources and particular opinions and agendas regarding the development process (Smith and Fischbacher 2005).

The six cases examined in this study were all service development projects that ran over a long period of time with a view to developing and transforming public transport to make it more modern and easily accessible to different groups of travellers. In this in-depth qualitative study of Swedish public transport, the concept of service development is taken to include the development of new services and/ or the refinement of existing services. In summary, the six cases are identified in Table 1.

\section{Data Collection and Analysis}

Most of the data were gathered from semi-structured interviews that were conducted face-to-face or by telephone. The interviews focused on the different actors and their roles in the service development process. All interviews were recorded and later transcribed. The data from the interviews were complemented by personal observations and documentary analysis.

Data analysis proceeded by inductive open coding (Miles and Huberman 2004) using the qualitative computer program Nvivo 7. After re-coding and sorting the data, the various actors involved in the service development process were identified. The coded data were then distilled into detailed descriptions of the various actors and their roles. Table 2 provides an overview of the collection of data in the six cases. 


\section{Table 1. Overview of Cases}

\begin{tabular}{|c|c|}
\hline Case & Description \\
\hline 1 & $\begin{array}{l}\text { The first case concerned the reconstruction of a bus route from a neighborhood } \\
\text { with many elderly residents to a shopping centre in a metropolitan area. This } \\
\text { case involved a variety of actors including local government officials, private } \\
\text { homeowners, private retailers, and interest groups representing the elderly and } \\
\text { disabled. The main focus of this case was the integration of these various actors } \\
\text { from the public and private sectors. }\end{array}$ \\
\hline 2 & $\begin{array}{l}\text { In the second case, a more comprehensive reconstruction of public transport } \\
\text { within a sparsely populated municipality was undertaken. The plan was to } \\
\text { create a totally new public-transport solution to reduce costs and increase } \\
\text { accessibility. To achieve these goals, the needs of different groups of travellers } \\
\text { (for example, schoolchildren and commuters) had to be integrated by } \\
\text { reorganising travel routes and timetables, rebuilding the physical infrastructure, } \\
\text { and encouraging the subcontractors to increase the quality of the public } \\
\text { transport provided. }\end{array}$ \\
\hline 3 & $\begin{array}{l}\text { The third case involved several minor projects jointly aimed at making public } \\
\text { transport more accessible to elderly and disabled travellers. This included the } \\
\text { development and implementation of a live traffic information system, the } \\
\text { rebuilding of bus stops, the reorganization of traffic routes, and a marketing } \\
\text { campaign regarding improved accessibility for the elderly and disabled. }\end{array}$ \\
\hline 4 & $\begin{array}{l}\text { The fourth case was a study of the long-term (6-8 years) development of a new } \\
\text { ticketing and information system involving collaboration among six Swedish } \\
\text { public transport authorities. The collaboration involved a formal project group } \\
\text { of four members with overall responsibility for the project; an advisory and } \\
\text { management board of managers of public transport authorities; large project } \\
\text { groups of approximately } 25-30 \text { participants representing different areas of } \\
\text { expertise within the Swedish public-transport sector; and smaller task groups } \\
\text { working on technical solutions to specific problems. In addition, an external } \\
\text { technical consultancy firm was engaged to build the actual ticketing system. The } \\
\text { ticketing and information system was based on a joint standard created by a } \\
\text { professional and industrial organization for the Swedish public-transport sector. }\end{array}$ \\
\hline 5 & $\begin{array}{l}\text { The fifth case was concerned with the long-term ( } 5-8 \text { years) development and } \\
\text { implementation of a new ticketing and information system by a single public } \\
\text { transport authority in one large Swedish city. The development process was } \\
\text { conducted jointly with a technical consultancy firm that was responsible for } \\
\text { developing the hardware and software for the project. At the beginning, the } \\
\text { project was run by a project group, but it subsequently involved } 8-10 \text { subgroups } \\
\text { that became responsible for developing and integrating various aspects of the } \\
\text { system. A major challenge was ensuring that the system suited the needs of } \\
\text { different groups of operating staff. As in Case 4, the ticketing and information } \\
\text { system in this case was again based on a joint standard created by a professional } \\
\text { and industrial organisation for the Swedish public-transport sector. }\end{array}$ \\
\hline 6 & $\begin{array}{l}\text { The sixth case concerned the development of the joint standard for Swedish } \\
\text { ticketing and information systems noted above in Cases } 4 \text { and } 5 \text {. This project } \\
\text { started almost a decade ago with the aim of creating a joint ticketing and } \\
\text { information system throughout the Nordic countries. More recently, a private } \\
\text { listed company was created to formalize the work of standardizing the } \\
\text { requirements. }\end{array}$ \\
\hline
\end{tabular}




\section{Table 2. Overview of Data Collection from Cases}

\begin{tabular}{|c|c|c|c|}
\hline Case & Project Task & Respondents & Documents \\
\hline 1 & $\begin{array}{c}\text { Redesign of parts of } \\
\text { transport system }\end{array}$ & $\begin{array}{c}\text { Project managers, members of } \\
\text { managerial group, users, traffic planners }\end{array}$ & $\begin{array}{c}\text { Internal project } \\
\text { documents }\end{array}$ \\
\hline 2 & $\begin{array}{c}\text { Redesign of parts of } \\
\text { transport system }\end{array}$ & $\begin{array}{c}\text { Project managers, traffic coordinator } \\
\text { transport system }\end{array}$ & $\begin{array}{c}\text { Research reports, internal } \\
\text { project documents }\end{array}$ \\
\hline 3 & $\begin{array}{c}\text { Redesign of parts of } \\
\text { chairman of the public transport board, } \\
\text { local politicians, users }\end{array}$ & $\begin{array}{c}\text { Intecuments } \\
\text { doct }\end{array}$ \\
\hline 4 & $\begin{array}{c}\text { Development of } \\
\text { information and } \\
\text { ticketing system }\end{array}$ & $\begin{array}{c}\text { Project managers, members of } \\
\text { managerial group, managing directors, } \\
\text { managers of subprojects }\end{array}$ & $\begin{array}{c}\text { Internal project } \\
\text { documents }\end{array}$ \\
\hline 5 & $\begin{array}{c}\text { Development of } \\
\text { information and } \\
\text { ticketing system }\end{array}$ & $\begin{array}{c}\text { Project managers, members of } \\
\text { managerial group, managers of } \\
\text { subprojects }\end{array}$ & Internal project \\
documents
\end{tabular}

\section{Results}

Based on the empirical analysis, eight main categories of actors were identified in the service-development processes studied here:

- Strategic Creators (or Institutional Initiators)

- Competing Actors

- Deciding Actors

- Supporting Actors

- Prime Movers

- Suppliers

- Service Performers (subcontractors, co-workers, and frontline staff)

- Users

Each of these groups had its own agenda, which, in various ways, facilitated or obstructed the development process. The eight groups of actors and their various roles are described in more detail in Table 3. 


\section{Table 3. Presentation of Empirical-Driven Actor Roles}

\begin{tabular}{|c|c|c|}
\hline Actor Role & $\begin{array}{l}\text { Description } \\
\text { of Role }\end{array}$ & Examples from Cases \\
\hline $\begin{array}{l}\text { Strategic } \\
\text { Creators (or } \\
\text { Institutional } \\
\text { Initiators) }\end{array}$ & $\begin{array}{l}\text { The actors that } \\
\text { provide the cen- } \\
\text { tral idea gover- } \\
\text { ning the } \\
\text { initiation of the } \\
\text { development } \\
\text { process. }\end{array}$ & $\begin{array}{l}\text { In some cases the central idea emanates from political actors } \\
\text { deciding about new or altered guide-lines considering the role } \\
\text { the public transport should play in the society. For example, in } \\
\text { the first three cases, governmental decisions concerning that } \\
\text { the public transport should be accessible to all travellers } \\
\text { (including senior citizens and disabled) set the framework for } \\
\text { and initiated the development processes. In other cases, the } \\
\text { Strategic Creators where local actors within the organization. } \\
\text { For example, in the fourth and fifth cases, the Strategic } \\
\text { Creators were the general managers of a number of public } \\
\text { transport authorities, who decided that they had to improve } \\
\text { the functions of the ticketing and information systems to } \\
\text { make it easier for travellers to obtain tickets and up-to-date } \\
\text { information about the service. This strategic decision triggered } \\
\text { the start of the development projects. }\end{array}$ \\
\hline $\begin{array}{l}\text { Competing } \\
\text { Actors }\end{array}$ & $\begin{array}{l}\text { The actors that } \\
\text { compete for the } \\
\text { same resources } \\
\text { as the studied } \\
\text { development } \\
\text { processes. }\end{array}$ & $\begin{array}{l}\text { An example was apparent in the third case, in which an } \\
\text { important actor in the service development project was the } \\
\text { construction contractor, who was responsible for building and } \\
\text { maintaining buildings and other infrastructure (such as } \\
\text { shelters at bus stops) to make them accessible to the elderly } \\
\text { and disabled. This was obviously an important aspect of the } \\
\text { service development undertaken in this case study. However, } \\
\text { this actor did not receive any extra funding for his } \\
\text { participation in this development project; rather, he was } \\
\text { forced to prioritise existing funding, which was also needed for } \\
\text { maintaining buildings in other public services (such as schools } \\
\text { and healthcare facilities). When he decided to favor } \\
\text { educational and healthcare facilities in preference to the } \\
\text { public-transport development project, this delayed the } \\
\text { reconstruction of bus shelters, and thus obstructed the } \\
\text { development project in general. }\end{array}$ \\
\hline $\begin{array}{l}\text { Deciding } \\
\text { Actors }\end{array}$ & $\begin{array}{l}\text { The actors that } \\
\text { decide about the } \\
\text { allocation of the } \\
\text { resources needed } \\
\text { for the develop- } \\
\text { ment processes. }\end{array}$ & $\begin{array}{l}\text { Due to the fact that there exists competition between } \\
\text { different projects, the actors deciding about the resources is } \\
\text { very important. The importance of having the support from } \\
\text { the deciding actors was clearly stated in the fourth case where } \\
\text { one of the members of the group leading the project made the } \\
\text { following observation: "By having the general manager of the } \\
\text { public transport authority on the management team of the } \\
\text { project, we ... have the necessary support ... everybody is } \\
\text { totally focused on this being something we have to do." }\end{array}$ \\
\hline $\begin{array}{l}\text { Supporting } \\
\text { Actors }\end{array}$ & $\begin{array}{l}\text { The actors that } \\
\text { provide direct or } \\
\text { indirect support } \\
\text { of various kinds } \\
\text { to the projects. }\end{array}$ & $\begin{array}{l}\text { An example of the need for actors that in different ways } \\
\text { support the development project could be seen in case five } \\
\text { where it was expressed that during the early phases of the } \\
\text { project: "All the managers [not only the deciding managers, } \\
\text { but all managers within the organization] have been on the } \\
\text { stage ... which indicates that this is very important." An } \\
\text { example of indirect support for development work was } \\
\text { identified in the first and third cases, in which interest groups } \\
\text { representing the elderly and disabled supported the politicians } \\
\text { in their efforts to provide better accessibility to public } \\
\text { transport. }\end{array}$ \\
\hline
\end{tabular}




\begin{tabular}{|c|c|c|}
\hline & & $\begin{array}{l}\text { she is the one who must be the driving force ... with the rest } \\
\text { of us in project management to support her ... there are also a } \\
\text { number of informal prime movers in the larger group working } \\
\text { with the development project." The Prime Mover was not } \\
\text { always a particular person; in some cases, there were several } \\
\text { individuals who worked together as motivators in the } \\
\text { development. This was the situation in the third case, in which } \\
\text { a group of enthusiastic actors with a variety of skills were the } \\
\text { Prime Movers in making public transport more accessible to } \\
\text { the elderly and disabled. A similar pattern was observed in the } \\
\text { fourth case, in which the actors in the central ticketing project } \\
\text { also worked as Prime Movers at the local level by engendering } \\
\text { enthusiasm among the local service-providers. }\end{array}$ \\
\hline Suppliers & $\begin{array}{l}\text { The external ac- } \\
\text { tors that } \\
\text { contribute as } \\
\text { suppliers of } \\
\text { know-how } \\
\text { and/or physical } \\
\text { resources that do } \\
\text { not exist inside } \\
\text { the project, } \\
\text { needed in the de- } \\
\text { velopment of the } \\
\text { service. }\end{array}$ & $\begin{array}{l}\text { In many cases the development projects was highly dependent } \\
\text { on external suppliers of know-how and physical resources. } \\
\text { Obvious examples of this could be seen in the fourth, fifth, and } \\
\text { sixth cases, in which the service development projects were } \\
\text { dependent on the development of a computerized ticketing } \\
\text { and information system. In these cases, these skills were } \\
\text { provided by an external supplier, since the principal actors in } \\
\text { the project did not possess the technical skills required. In the } \\
\text { fourth case, the project plan explicitly emphasised the } \\
\text { importance of collaboration with the external suppliers of the } \\
\text { technical solution. Indeed, a formal contract with the supplier } \\
\text { stipulated the obligations and responsibilities of the parties } \\
\text { with respect to the project. In the fifth case, the supplier was } \\
\text { responsible for working closely with other actors and } \\
\text { ensuring that the employees of the public transport } \\
\text { authorities and service-providers were able to manage the } \\
\text { technical system adequately. This went beyond the formal } \\
\text { stipulations of the contract to include the creation of a } \\
\text { trusting relationship, as one of the participants in the fourth } \\
\text { case observed: "I think it's been very important as regards how } \\
\text { things work socially with the supplier ... you're creating trust } \\
\text { between the supplier and yourselves." }\end{array}$ \\
\hline $\begin{array}{l}\text { Service } \\
\text { Performers }\end{array}$ & $\begin{array}{l}\text { In the Swedish } \\
\text { public-transport } \\
\text { system, the actual } \\
\text { service is pro- } \\
\text { vided by actors } \\
\text { outside the } \\
\text { public transport } \\
\text { authorities. These } \\
\text { subcontractors } \\
\text { are the actual } \\
\text { service } \\
\text { performers, and } \\
\text { these actors play } \\
\text { an important } \\
\text { role in the } \\
\text { development } \\
\text { process. }\end{array}$ & $\begin{array}{l}\text { The general manager of the public transport authority in the } \\
\text { third case made the following comment about these Service } \\
\text { Performers: "The relationship with the subcontractor is very } \\
\text { important. We are the ones responsible for the brand, who } \\
\text { receive the complaints, and we are therefore very keen for the } \\
\text { relationship with the subcontractor to function well." The } \\
\text { importance of having these actors involved in the development } \\
\text { process can be seen in the following statement by the deputy } \\
\text { manager of the project in the fifth case: "We have deliberately } \\
\text { selected who to involve in the project-based on the fact that } \\
\text { that they will be the ones working with the task later on ... As } \\
\text { a result of this, [we trust that] there will be no comment: 'Oh! } \\
\text { How's this going to work?' In addition to the } \\
\text { subcontractors, other important actors who come under cate- } \\
\text { gory of Service Performers included the frontline staff of the } \\
\text { organizations that participated in the development and } \\
\text { delivery of the service. }\end{array}$ \\
\hline Users & $\begin{array}{l}\text { The users play an } \\
\text { important role in } \\
\text { the development } \\
\text { process by con- } \\
\text { tributing with } \\
\text { information. }\end{array}$ & $\begin{array}{l}\text { The importance of having the users involved in the } \\
\text { development process was explained by the politician } \\
\text { responsible for public transport in the third projects: "We } \\
\text { have made a habit, before every major transportation change, of } \\
\text { having a meeting with representatives of the users in order to } \\
\text { inform and be informed ... This is something that's turned } \\
\text { out well." }\end{array}$ \\
\hline
\end{tabular}




\section{Discussion}

\section{Functional Roles in Service Development}

The categories of actors identified in the cases studied here differ somewhat from those revealed in Syson and Perks' (2004) case study. In their study, the actors were categorized based primarily on their formal designated positions in the company and/or the network. In the present case, the focus is more on their functional roles in the actual service development process. One reason for this is the fact that some actors can exist in more than one role in the service development process. For example, at various stages in the process, some general managers of the public transport authorities acted as Strategic Creators, Supporting Actors, Deciding Actors, and/or Prime Movers. The present study therefore contends that it is more appropriate to emphasise the functions of the various actors in the service development process rather than their designated positions as the primary basis for categorizing respective roles in service development.

Nevertheless, despite the present study's emphasis on functional role, it is still possible, like in Syson and Perks' (2004) case, to note that some of these functions are essentially "external" to the development process, whereas other functions are essentially "internal" to the process. The functions labelled as external included the functions of the Strategic Creators, the Supporting Actors, and the Competing Actors. None of these functions were involved in the service development process on a day-to-day basis; rather, these functions influenced the process from a more strategic level-by initiating the process (the Strategic Creators), supporting it (the Supporting Actors), or competing with it to obtain resources (the Competing Actors). In contrast, some functions were essentially "internal"; these included the functions of the Prime Movers, the Suppliers, the Service Performers, and the Users. These functions actually performed (or were at least involved in) the dayto-day development process. The function of the remaining group, the Deciding Actors, can be seen as both internal and external because the functions of this group operated on several levels.

\section{A Conceptual Model}

On the basis of the above discussion, the present study proposes a conceptual model of relationships among the various functional roles of actors in the service development process. As shown in the figure, the functions can be divided into external functions (those outside the shaded box) and internal functions (those within the shaded box). 


\section{Figure 1. Conceptual Model of Functional Roles in Service Development}

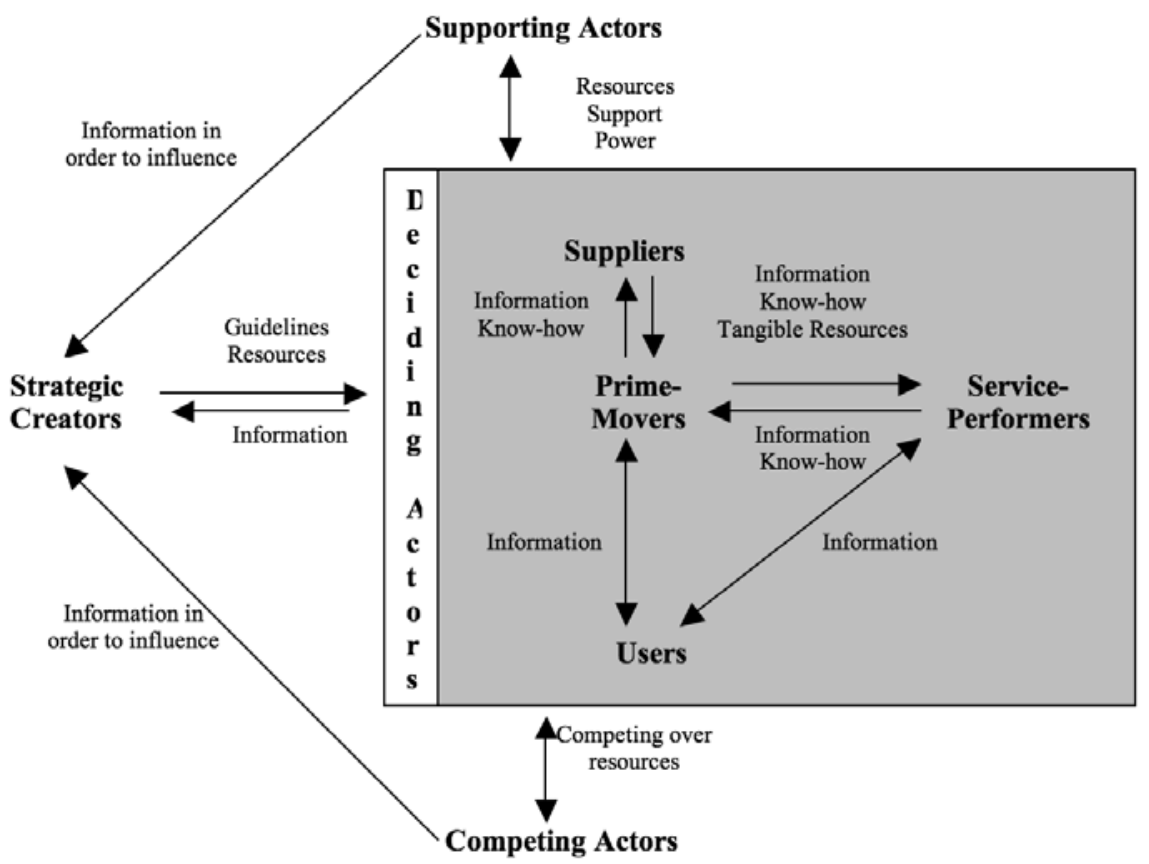

\section{External Functions}

As shown in the proposed model, the strategic creators initiated the service development process by creating (and, if necessary, amending) the strategic guidelines for the service offering that was to be delivered. The main functions of this group included strategic decision-making about what was to be developed, setting the financial parameters, approving funds, and directing the resources required to realize the overall strategy.

The second group of external functions illustrated in the model shown in Figure 1 is those of the Competing Actors. As previously noted, this group competed for limited resources to provide the services that they perceived to be important. In doing so, they used information to apply pressure to the strategic creators and deciding actors. The nature of their competition differed significantly from that of the group labelled competitors in the study of Syson and Perks (2004). In the latter case, the competitors competed with actors in the same line of business to secure customers. In contrast, in the cases studied here, the actors had a monopoly status within a certain geographical area; competition in this setting therefore consisted 
of various public-sector bodies attempting to secure priority in the allocation of limited government resources. The Competing Actors were thus to be found in quite disparate areas of the public sector.

The third group of external functions illustrated in Figure 1 is that of the Supporting Actors. The main inputs from this group are to provide resources, support, and power to the internal functions of the project and to provide information with a view to influencing the strategic creators. To some extent, the equivalent functions in Syson and Parks' (2004) study were those of the senior management team and other internal actors who provided a green light to the projects and thus provided some degree of formal support.

The functions of the Deciding Actors are illustrated on the left side of the shaded box of Internal Functions. These actors considered the claims of the competing actors and had the power to decide how the limited available resources would be utilised in the project. They received guidelines and resources from the strategic creators and provided information in return.

\section{Internal Functions}

The principal internal function illustrated in the shaded box in Figure 1 is that of the Prime Movers. As previously noted, the Prime Movers in the cases studied here were actors who were committed and enthusiastic about service development and who assumed responsibility for ensuring that service development proceeded. They made the strategies operational by transforming them into practical service offerings. It is noteworthy that a Prime Mover could be an actor without any formal power in the development process, provided that person (or organization) was strongly committed to creating a good service. In other cases, the Prime Mover can be commissioned with the specific task of leading the service-development team. Moreover, the identity of the Prime Mover can change during the development process. The main resources of this group were know-how and information concerning the processes and the service in general. In addition, they sometimes had control over certain resources approved for the project. This group can be compared with Syson and Perks' (2004) product development team-although the function of the Prime Movers in the present study was less formalized and was not always undertaken by a team of actors.

The second group of internal functions shown in Figure 1 is those of the Service Performers. They represented an important function during the development process. However, as previously noted, a major challenge in the development 
processes studied here was to overcome the restraints imposed by the contractual tendering arrangements imposed by statute on the relationship between the public transport authorities and their subcontracting performers of services.

Although the Suppliers are shown in Figure 1 as fulfilling internal functions, in some of the cases studied here the high-tech aspects of the service (such as information and ticketing systems) required the expertise of an external supplier. The need for such external input is ultimately derived from the acknowledged need for organizations to interact and develop relationships in order to acquire and utilise resources (Turnbull and Wilson 1989). In other cases, the Suppliers were internal agents within the service development process. The precise arrangements with suppliers can thus vary, but, whatever the arrangement, there is a need for close day-to-day interaction during the finalization and implementation of the system under development. Apart from ensuring that the systems work, it is important to transfer the necessary knowledge and know-how from the suppliers to the operators of the system. The Suppliers were an important actor group in the present study, and their function is accordance with the Suppliers in Syson and Perks' (2004) study, who were also identified as important actors in the service development process.

The last group of internal functions identified in the present study was the Users. As described in the service development literature, they had an important function because they were both the user and co-producers of the service (Berry and Hensel 1973; von Hippel et al. 1999; Pitta and Franzak 1996; Edvardsson 1997). However, problems exist with respect to identifying which users should be involved and how they should be involved. This group was also identified by Syson and Perks (2004) as important actors in the development process.

Finally, it should be noted that this study has shown that the main contributions made by most actors in the service development process are information, knowledge, and expertise, which are all intangible resources. In many cases, these intangible resources are tacitly assumed within an organization, thus inhibiting access by other actors. The present study thus endorses the findings of Syson and Perks (2004), who noted that closeness and informal communication among actors is an important means of generating and accessing the tacit knowledge required for service development. 


\section{Conclusions, Managerial Implications, and Future Research}

Although many studies have focused on new service development, relatively little research has been undertaken into which actors participate in the service development process, the roles they play, and the resources they bring to the development process. On the basis of six case studies of service development in the public sector, eight groups of actor functions have been identified. Four of these functions were labelled as "external" because they were not involved in a day-to-day basis in the development process, but contributed at a strategic level by initiating the process, supporting it, or competing with it for limited resources. These functions were designated as the Strategic Creators (or Institutional Initiators), the Supporting Actors, the Deciding Actors, and the Competing Actors. In contrast, the "internal" functions actually performed (or were at least involved in) the day-to-day development process. These were designated as the Prime Movers, the Suppliers, the Service Performers, and the Users.

Certain implications for theorists as well as managers flow from the present study. They can be summarized as follows. First, it is important to realize that the service development process is complex and that there exist many different actors needed to be handled in the development process. To manage a service development process under this studied contextual situation, there is a need to understand what different functional roles that exist in the process. In contrast to Syson and Perks' (2004), this study highlights that the important thing to focus on is the actors' functions rather than designated positions. An actor can, despite his/her formal position, appear in many functions and thereby be driven by different logics and have different power and different agendas, depending on their function for the time-being. When managing the service development process, one must be aware of the functional roles creating the prerequisites for the development process and the functional role carrying out the actual work when it comes to developing the service. Based on this, it is important to provide each functional role with the right type of resources. When it comes to the group of functions setting the arena for the development process (i.e., the Strategic Creators and the Deciding Actors), it is important to supply them with the right kind of information, helping them in making decisions propitious for the development project. In this, the Supporting Actors are very important since they in their function can help the Deciding Actors and the Strategic Creators make the right decisions.

When it comes to the group that, on the other hand, functions as the actors actually developing the service, they need other types of resources. In many cases, their 
development work consists of different kind of knowledge transfer and knowledge sharing, and for facilitating this kind of processes there are other supporting activities necessary. The knowledge needed is created by constant interactions with other actors where information is shared and transferred. In this, dialogue is an important aspect, something that is also highlighted by Syson and Perks (2004), who claim that closeness between actors and informal communication mechanisms is an appropriate means for generating this kind of knowledge. Relational capital (trust) facilitates the transfer of tacit knowledge between collaborating partners, due to the fact that transfer of tacit knowledge to a high extent is about inter-personnel communication (Collins and Hitt 2006).

Seen from this perspective, service development is made up of interactions. Ireland et al. (2002) assert that effective knowledge transfer does not occur automatically; it requires deliberate management and attention to the transfer process. Processes facilitating learning must be planned and organized. In the management of an effective service development process, these kinds of activities must be handled well to create right conditions for the ones conducting the actual service development process.

Using this study as a starting point, a number of research opportunities can be identified. First, this study should been seen as merely an initial step in the categorization process. Future studies could expand on the present findings by focusing on the resources that the various actors contribute during the development process. This could perhaps lead to a modification of the categorization suggested here. Second, because this study was conducted only within the context of the public sector, it would also be of interest to study actor roles in service development processes conducted within the private sector. Third, future studies could aim to increase understanding of how service development proceeds as an individual and/or organizational learning process. Such studies could investigate how different actors' knowledge and other resources are transformed into a new or refined service offering.

\section{References}

Akamavi, R.K. 2005. A research agenda for investigation of product innovation in the financial services sector. Journal of Services Marketing 19/6: 359-378. 
Atuahene-Gima, K. 1996. Differential potency of factors affecting inno $\neg$ vation performance in manufacturing and services firms in Australia. Journal of Product Innovation Management 13: 93-103.

Berry, L.L., and J.S. Hensel. 1973. Why some new bank products fail. Bankers Monthly Magazine, July 15, pp. 26-40.

Bowers, M.R. 1988. Developing market-driven insurance products: A suggested model. Journal of Professional Services Marketing 3(3/4): 161-173.

Collins, J.D., and M.A. Hitt. 2006. Leveraging tacit knowledge in alliances: The importance of using relational capabilities to build and leverage relational capital. Journal of Engineering and Technology Management 23: 147-167.

deBurca, S. 1995. Service management in the business-to-business sector: From networks to relationship marketing. In Glynn, W. B., and Barnes, J. G. (ed.), 1995, Understanding service management-Integrating marketing, organisational behaviour, operations and human resource management. Chichester: John Wiley \& Sons.

Edgett, S. 1996. The new product development process for commercial financial services. Industrial Marketing Management 25.

Edvardsson, B. 1997. Quality in new service development: Key concepts and a frame of reference. International Journal of Production Economics 52: 31-46.

Edvardsson, B., A. Gustafsson, M.D. Johnson, and B. Sandén. 2000. New service development and innovation in the new economy. Lund: Studentlitteratur.

Ford, D (ed.). 1997. Understanding business markets: Interaction, relationships and networks, 2nd edition. London: Dryden Press.

Grönroos, C. 1990. Service management and marketing: Managing the moments of truth in service competition. Lexington, Massachusetts: Lexington Books.

Heikkinen, M.T., T. Mainela, J. Still, and J. Tähtinen. 2007. Roles for managing in mobile service development nets. Industrial Marketing, Management 36: 909-925.

Håkansson, H., and J. Johansson. 1992. A model of industrial networks. In Axelsson, B., and Easton, G. (eds.). 1992. Industrial networks: A review of reality. London: Routledge. 
IMP. 1982. An interaction approach. In Håkansson, H. (Ed). 1982. International marketing and purchasing ofilndustrial goods-An interaction approach. London: John Wiley.

Ireland, R.D., M.A Hitt, and D. Vaidyanath. 2002. Alliance management as a source of competitive advantage. Journal of Management 28: 413-446.

Johne, A., and C. Storey. 1998. New service development: A review of the literature and annotated bibliography. European Journal of Marketing 32(3): 184-251.

Johnson, S.P., L.J. Menor, A. V. Roth, and R. B. Chase. 2000. A critical evaluation of the new service development process. In Fitzsimmons, J.A., and Fitzsimmons, M.J. (eds.). 2000. New service development: Creating memorable experience. Thousand Oaks, CA: Sage Publications Inc.

Jong, de, J.P.J., and P.A.M. Vermeulen. 2003. Organizing successful new service development: A literature review. Management Decisions 41(9): 844-858.

Lievens, A., R. Monaert, and S. S'Jegers. 1999. Linking communication to innovation success in the financial service industry: a case study analysis. International Journal of Service Management 10(1): 24-37.

Martin, C.R., and D.A. Horne. 1993. Service innovation: Successful vs. unsuccessful firms. International Journal of Service Industry Management 4: 48-64.

Miles, M.B., and A.M. Huberman. 2004. Qualitative data analysis. London: SAGE Publications.

Pitta, D., and F. Franzak. 1996. Boundary spanning product development in consumer markets: Learning organization insights. Journal of Consumer Marketing 13(5): 66-81.

Scheuing, E., and E. Johnson. 1989. A proposed model for new service development. The Journal of Service Marketing 3(2).

Schneider, B., and D.E. Bowen. 1985. New services design, development and implementation and the employee. In George, W.R., and Marshall, C.E. (eds.). Developing new services. American Marketing Association Proceedings: 82-101.

SLTF. 2002. Public transport in Sweden: Coordination and competition. Stockholm: SLTF.

Smith, A., and M. Fischbacher. 2005. New service development: A stakeholder perspective. European Journal of Marketing 39(9/10): 1025-1048. 
Stevens, E., and S. Dimitriadis. 2004. New service development through the lens of organisational learning, evidence from longitudinal case studies. Journal of Business Research 57: 1074-1084.

Syson, F., and H. Perks. 2004. New service development: A network perspective. Journal of Services Management 18(4): 255-266.

Turnbull, P., and D. Wilson. 1989. Developing and protecting profitable customer relationships. Industrial Marketing Management 18: 233-238.

von Hippel, E., S. Thomke, and M. Sonnack. 1999. Creating breakthroughs at 3M. Harvard Business Review. September-October.

\section{About the Author}

PatrIK GottrRIDsson (Patrik.gottfridsson@kau.se) holds a PhD in Business Administration from the Service Research Center attached to Karlstad University in Sweden. His research mainly focuses on service development, network theory, and relationship management. 